\title{
IMPACT OF LEARNING PROCESS IN FASHION STUDENTS: LINK WITH INDUSTRY, SOCIAL MEDIA AND WEBSITES
}

\author{
António Dinis Marques \\ University of Minho (PORTUGAL)
}

\begin{abstract}
The Portuguese fashion industry (textile, apparel and footwear) shows an excellent economic performance in the last years. With own brands, own collections and own products, the quality, the innovation and international image of the Portuguese clothes, accessories and shoes is increasing year by year.

University of Minho has the Bachelor in Fashion Design and Marketing (BFDM). The young students came from different schools and places, with different backgrounds and links with fashion issues. The fashion industry needs good professionals to design and marketing functions, but these skills have to be worked in the university.

Facebook, Instagram, Twitter and other social media are opportunities that the companies want to grab to promote and sell their products to the new global consumer. The Bachelor in Fashion Design and Marketing applies time and resources to increase the use and knowledge in these new tools. But remains an important question: does it works?
\end{abstract}

To answer this question was designed this investigation. It is a qualitative research and the methods were "focus group" and longitudinal analysis. During January and February a focus group with ten young students from BFDM first year participated in two sessions. After an individual analysis of three different fashion brands (with presence in websites, facebook and Instagram), according a matrix designed to the investigation, the researchers made a discussion with the group.

The results are very interesting and they will be used to evaluate the changes in the skills of the future fashion designers, before and after the bachelor degree in Fashion Design and Marketing. But they are preliminary results. In the future, we are planning to compare the results with students in BFDM and other bachelor degrees (without any link with fashion issues or interests).

The fashion industry is ready to get inside this new, global and social world. The skills of the new professionals need to be prepared to reply these new demands.

Keywords: Learning, fashion students, design, social media, websites.

\section{INTRODUCTION}

The textile, clothing and footwear industry belong to the "fashion industries". Indeed, there are many similarities between the footwear industry and the textile/apparel industries (ITV) in Portugal. They are traditional, "low-tech" and labor intensive, with a strong position in the Portuguese economy and represent thousands of jobs. They export more than other Portuguese labor-intensive industries, mainly to Europe, and contribute to a positive trade balance [1].

The Portuguese footwear industry has shown a remarkable performance in the last five years, better than others "fashion industries". It's a traditional industry, an industry mature and consolidated, with a long story in the Portuguese economy. Year by year this industry is stronger, creates new skills and increases his competitive position between the global players and competitors, even in sophisticated European markets, such Italian or French.

University of Minho has the Bachelor in Fashion Design and Marketing (BFDM) since 2006. After ten years of history, we can say that the young students came from different schools and places from Portugal, with different backgrounds, skills and motivations, and with different links with fashion issues. The fashion industry needs good professionals to the design and marketing functions, but these skills have to be worked in the university by the professors and other technicians, some of them linked with the fashion value chain and with the industry.

Frequently, fashion is referred as being a form of non-verbal expression of communication and, many times, of seduction. Clothing, jewellery and shoes, as fashion items, may be considered as an 
expression as how people wish themselves to be seen by other individuals, as well as a way of belonging to a particular group or as a representation of a particular lifestyle, or a culture, or a social category [2]. Harriet Posner [3] defines "style tribes" as groups of people known to each other or not, with the same ideas and values, styles, tastes and behaviours, and it can describe also a group of people who dresses with a common distinctive style.

The emergence of new information technologies, the development and exploration of virtual world and the arising of social networks during the last decades caused several changes, both in the lives of individuals and in business environment and/or competitive conditions, opening up new possibilities and challenges, as well as globally changing individual's consumption behaviour. The new information economy presents a new set of opportunities and threats to established companies, new challenges and new markets, and demanding to almost all companies to rethink their strategy and to prepare new business plans. We can say that this sort of transformation is inevitable, each type of industry will change according with its own dynamic, and these changes will occur at different velocities, with varying intensity and following different stages [4].

Firms are starting to perceive that the brand's transition to social media means a transformation of the customer relationship, wherein social media and the community members is an ally of the brand and not an "audience" [5]. The marketers can use social networks to identify how users are perceiving and/or interacting with their brand and open up new roads to communicate with them.

Social media has changed the world we market in, and can be used as an integral part of an online marketing campaign, with a specific plan. May say that social media is all about the ways that we create, connect and share online [6]. Social networks allow direct connections with people who are interested in their products and brands. The fashion blogs allow the discussion among participants, being more than a place to put information and news [7]. They participate in the information production and are active in the communication process.

Regarding the marketing and its strategies, the new communication channels almost have made traditional communication strategies obsolete and of little use [8]. However, new information technologies are not a replacement of traditional marketing tools and of their possibilities, but it is a complementary tool that has as an advantage of easy communication worldwide [9], whereas marketing primary objective continues to focus in satisfying individuals and organisation's needs of companies, other organizations and their brands [10].

The BFDM students have an obvious interest in fashion themes, and as they are "millennials" generation, the interaction with the new information technologies is stronger. Millennials are the world's current young adults, born between 1980 and 2000. This generation is also named as "Y" generation, net generation, echo boomers, next generation, boomerang generation or the Peter Pan generation, have an important purchase power. As said Neil Howe and William Straus [11], "this generation is going to rebel by behaving not worse, but better" and "their life mission will not be to tear down old institutions that don't work, but build up new ones that do". The skills and knowledges of BFDM students in Information and Communication Technologies (ICT) are very high. Almost all of them have smartphones, some have tablets and other gadgets, they use Facebook, Instagram, Pinterest and Tumblr, and they use also the learning tools proposed by the University during the classes (BlackBoard ${ }^{\mathrm{TM}}$ ). As states the World Youth Report [12], "children and young people must be provided with opportunities to acquire skills in multiple literacies to enable them to develop their identities, social relationships and communities, whether material, virtual, or a combination of the two". Inside this "media culture" is important to learn multiple ways of interacting with social reality [13], including the fashion items proposed by the fashion industries. The universities and schools can be sanctuaries of closed knowledge, protecting its educational autonomy with every means and resources available [14], but this closed code may be contrasted with the open code of internet and social media. ICT can be for the media-savvy teacher a never-ending source of information and pedagogical challenges [12]. That's what the researchers will try to do and study in the next steps of this work.

In recent years it can be seen that, in general, fashion brands embraces new technologies and also recognizes the importance of digital platforms, such as websites, blogs and social network, and it allows instant access to the global markets. Brands and consumers can communicate between themselves without having any restriction in time and place, non-geographically bound. It can be affirmed that old method of "one-way communication" had been shifted to interactive "two-way communication", meanwhile, brands can gain exposure and strengthen relationships with their customers [15]. 


\section{METHODOLOGY}

The methodological approach to the research was defined considering the specificities of the sector, the characteristics of the BFDM students and the proposed research objectives. The research methodology can be quantitative or qualitative: the qualitative analysis is presented as the most recommended when the researcher wants to study a small sample of entities and the study is focused on a theme, subject or sector [16],[17]. It is also recommended when the investigation aims obtaining detailed and in-depth information on situations, events, people, organizations, interactions and behaviors observed by the investigator during the field research [18]. When the industrial sector consists mainly of SMEs, as they are the "fashion industries", the qualitative approach is recommended to reduce the distance between the administrator or owner and the investigator [19].

The classification of study types that are most often used in qualitative methods of investigation classifies them as exploratory, descriptive and explanatory studies, however their implementation research can have more than one purpose [17]. To achieve successful investigation it is intended to gather a broad description of selected companies and their strategies throughout the fieldwork that meets the criteria of the descriptive study, as a comprehensive study it attempts to explain the observed relationships between the different variables. Therefore, will be conducted three case studies of Portuguese footwear companies, collecting data through document analysis (including websites and social media), through a longitudinal analysis in order to understand whether there are digital marketing and communication strategies implemented, and also strategies for development of content in different platforms and the benefits and obstacles of digital platforms. The case study arises from the desire to understand complex social phenomena, allowing the researcher to focus on a case and maintain a holistic perspective [16].

To collect certain primary data it was defined to use a group of people - focus group. According to David Carson et al [20] focus group is used as research methodology and can be justified with regard to data collection, with the depth of understanding, flexibility and interaction with a group, as well as for generation of knowledge about the sources of complex behaviours and motivations of each individual of the focus group. Usually, focus groups have from 4 to 8 participants, and in some cases can reach a number of 12 participants, where researcher takes a place of moderator, wherein this situation particularly justifies the collaboration for a moderator that is familiar with a discussion topic [17],[20]. In this case, the focus group had 10 students.

The longitudinal research of investigation serves two main purposes, in which the first one is focus on a description of the changing patterns, and the second is to establish a direction and magnitude of the causal relationships [21]. In this work, it is intended to develop a longitudinal analysis of the same brands of the case studies, observing their websites and social network account pages. To do it, were taken the data with pre-established criteria of the action's brand, and linked with the consumer responsiveness to the published content in periods of every week, during six months (Table 1). According to Scott Menard [21], in the longitudinal analysis, the variables are evaluated repeatedly over different periods, thus allowing measuring differences or changes in each of the variables. $\mathrm{He}$ describes different types of longitudinal analysis, however, for the desired analysis, the most adequate is the type of prospective panel, in which data can be collected in two or more distinct periods, with the same set of cases and variables in each period.

The combination of these two different strategies, - focus group and longitudinal analysis -, with the three brands selected, - Fly London, Lemon Jelly and Josefinas -, required an intensive follow up of the several steps and phases by the researchers. 
Table 1: Generic matrix to focus group and longitudinal analysis

\begin{tabular}{|l|l|l|}
\hline Website variables & Facebook variables & Instagram variables \\
\hline Women product renewal & Page likes & Followers \\
\hline Content update & Content update & Content update \\
\hline Website global ranking & Engagement & Likes \\
\hline Daily page views per visitor & Shares & Comments \\
\hline Daily time on site & Post likes & \\
\cline { 1 - 2 } Bounce rate \% & Comments & \\
& Visitor posts & \\
\cline { 2 - 2 } & Brand responsiveness to comments &
\end{tabular}

\section{GLOBAL FRAMEWORK}

Portuguese footwear companies with own products, with own collections and own brands, have different strategies to approach their markets. The last years had shown a very active industrial sector, trying to get inside new markets, with a common communication strategy. "The Sexiest Industry in Europe" was a marketing campaign that APICCAPS (Associação Portuguesa dos Industriais de Calçado, Componentes e Artigos de Pele e seus Sucedâneos) had launch and reached a very positive impact in the international image of the Portuguese footwear sector.

The focus group made a discussion about three footwear companies. Josefinas is the youngest brand and started his activity in 2012. Josefinas is a luxury brand, which is steadily building brands recognition nationally and internationally through trendsetters, well known fashion bloggers and fashion press, with appearance in such magazines as Vogue and Vanity Fair (Fig.1).

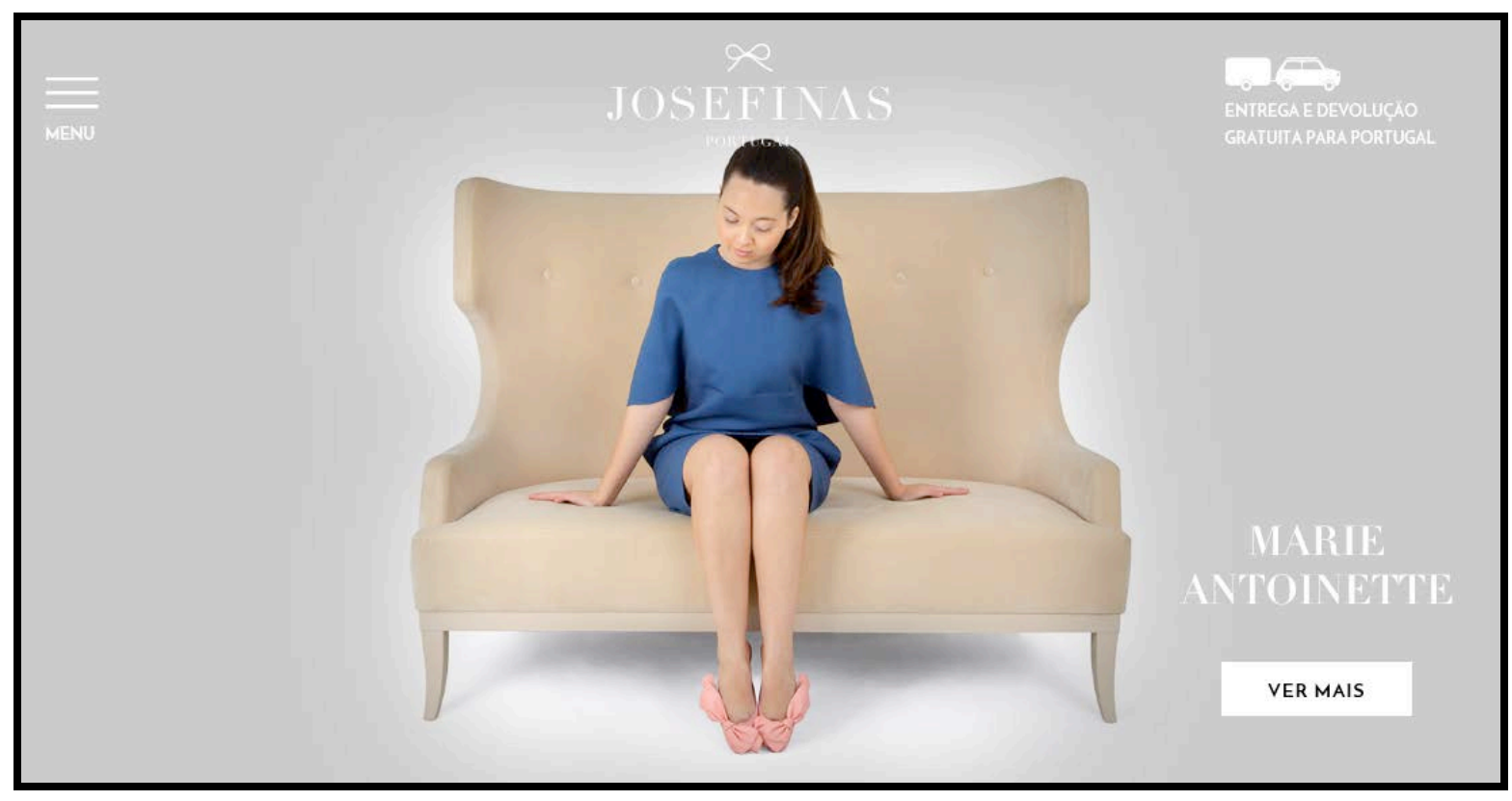

Figure 1: Website of Josefinas (accessed at $17^{\text {th }}$ of May 2016)

Lemon Jelly is a footwear fashion brand that belongs to Procalçado. The Procalçado's value chain integrates different technologies according the final products and made a technological upgrade from components (soles) till moulded footwear that occurred over than 40 years. 
In 2013 Procalçado have begun a new adventure. Starts with a fashion injected footwear project, associated to a new concept and brand: Lemon Jelly. Lemon Jelly is one of the emerging brands of the footwear sector in Portugal, which already received several innovation awards, since 2013 (Fig.2).

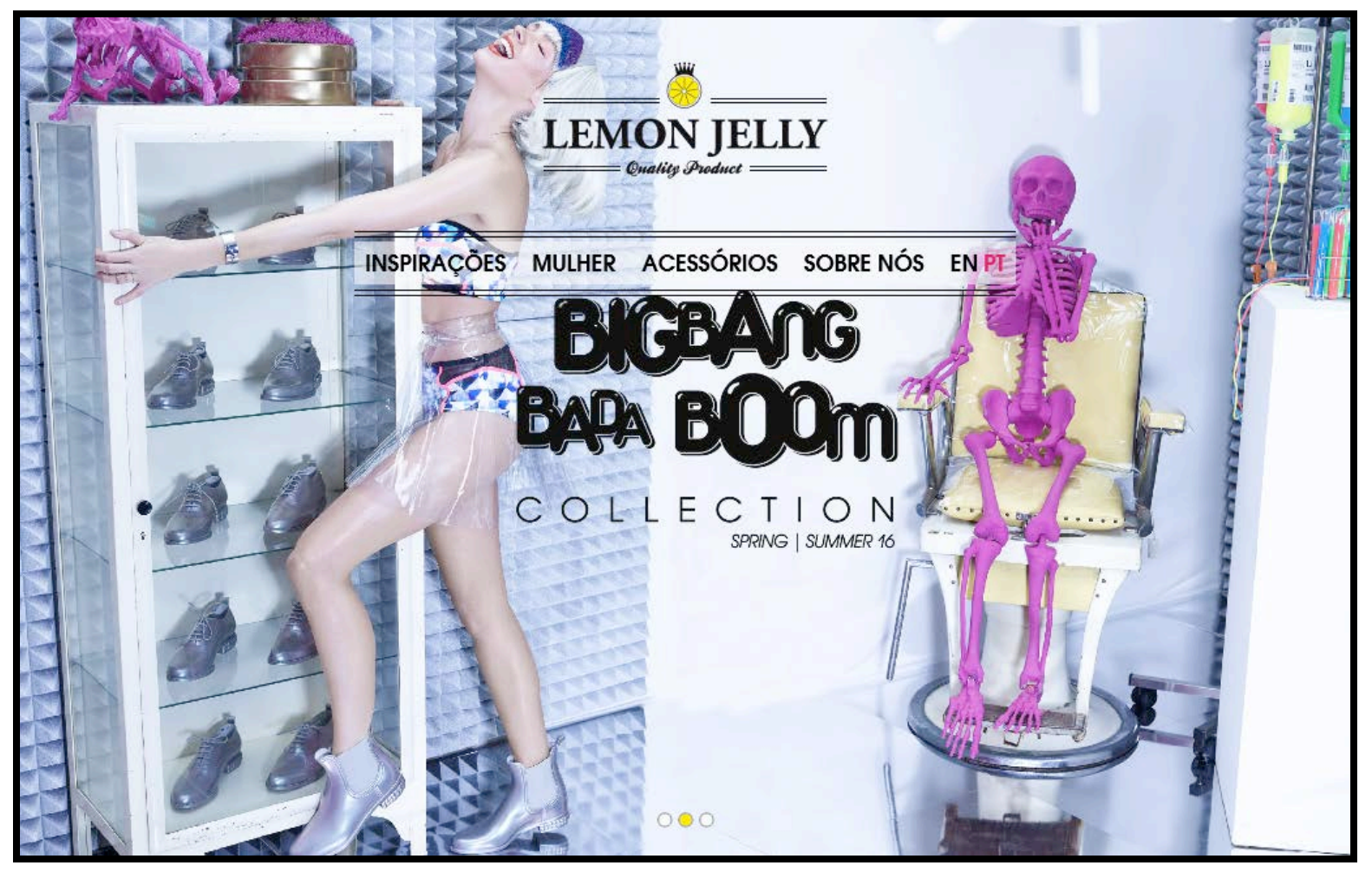

Figure 2: Website of Lemon Jelly (accessed at $17^{\text {th }}$ of May 2016)

Fly London is the oldest brand considered in the research, and, simultaneously, the brand with more sales (Fig.3). Has own shops in London, Dublin, New York and Lisboa. Additionaly, we can find their collections in multibrand shops all around the world. Kyaia participates in "HighSpeedShoeFactory" project. In this project, a consortium have prepared a radical solution to work "fast fashion": they can design, produce and deliver a customized shoe to a European customer in a maximum of two days.

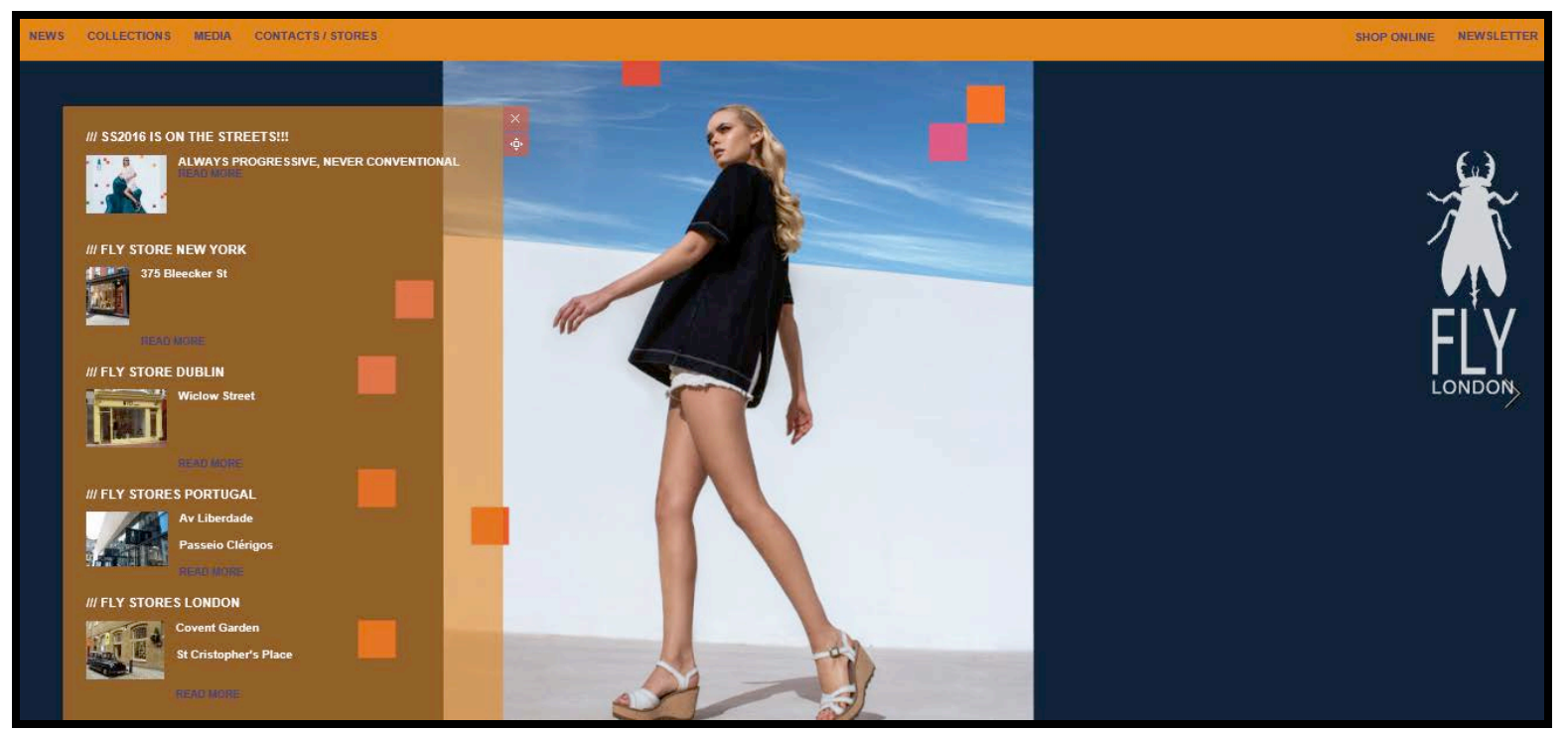

Figure 3: Website of Fly London/Kyaia (accessed at $17^{\text {th }}$ of May 2016) 
The three brands considered do not have a presence in all existing social networks (Table 2), consequently the longitudinal research will be conducted observing the chosen brands through Websites, Facebook and Instagram, since all brands have presence in these digital platforms.

Table 2: Presence in social media

\begin{tabular}{|c|c|c|c|c|c|c|c|}
\hline Brand & Website & Facebook & Google+ & Instagram & Twitter & Pinterest & Tumblr \\
\hline Fly London & Yes & Yes & No & Yes & No & No & No \\
\hline Lemon Jelly & Yes & Yes & No & Yes & No & Yes & No \\
\hline Josefinas & Yes & Yes & Yes & Yes & Yes & Yes & Yes \\
\hline
\end{tabular}

Table 3: When started in social media

\begin{tabular}{|l|l|l|}
\hline Brand & Active in Facebook since & Active in Instagram since \\
\hline Fly London & July of 2010 & September of 2015 \\
\hline Josefinas & May of 2013 & June of 2013 \\
\hline Lemon Jelly & March of 2013 & July of 2013 \\
\hline
\end{tabular}

Therefore, the analysis will be able to have a proper comparison for each brand. The longitudinal analysis started in January and will continue until July in order to complete the summer season, and will be fully filled with observations in different platforms: websites and social networks.

\section{DISCUSSION AND FINAL CONSIDERATIONS}

Companies in the fashion value chain have to continue investing into new information technologies, using the digital platforms like social network, as a way to be present in global markets and to be able to communicate with its customers. Investments in this area should involve obtaining benefits for the brand, creating communication, enhancing customer experience and strengthening relationships between its customers, and lastly but not least, building an appropriate image of the brands that decide to follow this approach.

The discussion in the focus group shows that developing a web site or to being in the social media for the fashion brands, involves more than choosing colours and header images. Aesthetic design isn't the more important factor in the websites. Usability is the one of the most important factor that has to be considered when developing a website. Navigation, Language and Content, or Architectural and Visual Clarity are critical elements in the usability analysis and these parameters were valued positively by the students. Search engine visibility is usually considered as factor to evaluate websites, but in our case this parameter wasn't considered. The conclusions reached during the sessions of the focus group are preliminary and, by ethical reasons, they need to be more worked and after to be communicated to the three companies. The students of fashion that participated in the focus group (ten millennial women) made many suggestions to improve the general performance of the three websites.

We are living a new Technology Wave. It involves disruption in several scientific areas, and obviously includes the new technologies of information and communication. The emergence of these new information technologies, created a disruption of the traditional communication strategies between fashion brands and consumers. And the fashion students are also millennial consumers of fashion brands.

The fourth industrial revolution, which was a central theme of the last World Economic Forum (WEF) in Davos, January 2016, will require improvements in the skills and knowledges of future workers of the companies. It is necessary to develop a profile of the students in new technology areas, an interdisciplinary academic context, fostering the development of new talent in the designated "Creative Class" in areas such as science, the arts, design or media. They must be provided with opportunities to acquire skills and knowledges in multiple literacies to prepare them to develop their identities, social relationships and communities, whether in physical or virtual/digital way. 


\section{ACKNOWLEDGMENTS}

"This work is financed by FEDER funds through the Competitivity Factors Operational Programme COMPETE and by national funds through FCT - Foundation for Science and Technology within the scope of the project POCI-01-0145-FEDER-007136".
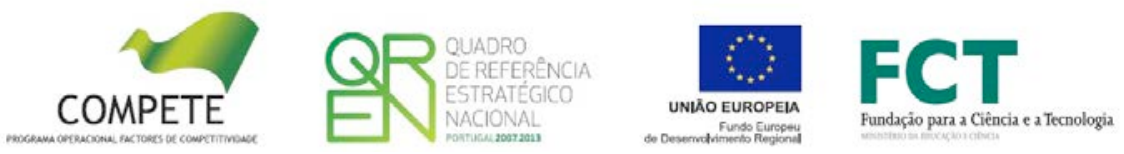

\section{REFERENCES}

[1] APICCAPS (2015). World Footwear Yearbook. Porto: APICCAPS.

[2] Easey, M. (2009). Fashion Marketing. Oxford: A John Wiley \& Sons Ltd.

[3] Posner, H. (2011). Marketing Fashion. London: Laurence King Publishing.

[4] Evans, P. and Wurther, T.S. (1997). Strategy and the New Economics of Information. Harvard Business Review, 75, pp.71-82.

[5] Phan, M., Thomas, R. and Heine, K. (2011). Social Media and Luxury Brand Management: The Case of Burberry. Journal of Global Fashion: Bridging Fashion and Marketing. 2(4), pp.213-222.

[6] Stokes, R. (2008). eMarketing:The Essential Guide to Online Marketing. Cape Town: Quirk eMarketing (Pty), Ltd.

[7] Reed, J. (2012). Marketing online: como usar sites, blogs, redes sociais e muito mais. São Paulo: Lafonte.

[8] Baires, P., Fill, C. and Page, K. (2013). Essentials of Marketing. Oxford: Oxford University Press.

[9] Brandt, K. S. (2008). You Should be on YouTube. ABA Bank Marketing. 40(6).

[10] Blythe, J.( 2005). Essentials of Marketing. London: Pearson Education Limited.

[11] Howe, N. and Strauss, W. (2000). Millennials Rising: The Next Great Generation. New York: Vintage Books.

[12] United Nations (2004). World Youth Report 2003. New York: United Nations Publications.

[13] Kellner, D. (1998). Multiple literacies and critical pedagogy in a multicultural society. Educational Theory, 48 (1), p.122.

[14] Willis, P. (2000). The Ethnographic Imagination. Cambridge: Polity Press.

[15] Kim A. J. and Ko E. (2010.) Impacts of Luxury Fashion Brand's Social Media Marketing on Customer Relationship and Purchase Intention. Journal of Global Fashion Marketing: Bridging Fashion and Marketing. 1(3), pp.167-171.

[16] Yin, R. K. (2009). Case Study Research: Design and Methods. London: Sage Publications Inc.

[17] Saunders M., Lewis P., Thornhill A. (2009). Reseach Methods for Business Students. London: Financial Times Prentice-Hall.

[18] Patton, M. Q. (1987). How to Use Qualitative Methods in Evaluation. California: Sage Publications Inc.

[19] Hill, J. and McGowan, P. (1999). Small Business and Enterprise Development: Questions about Research Methodology. International Journal of Entrepreneurial Behaviour and Research. 5(1), pp. 5-18.

[20] Carson D., Gilmore A., Perry C., Gronhaug K. (2001). Qualitative Marketing Research. Sage Publications.

[21] Menard, S. (2002). Longitudinal Research. Sage Publications, Inc. 